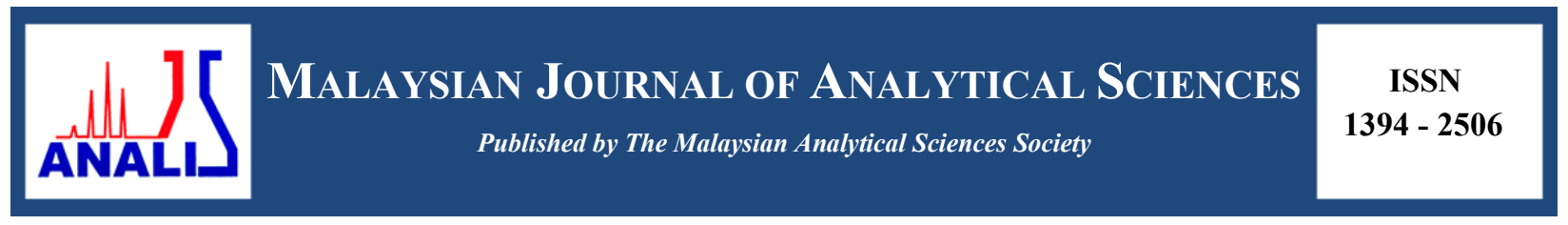

\title{
THE EFFECT OF GLUCOSE ADDITION IN ACETONE-BUTANOL- ETHANOL FERMENTATION FROM PALM OIL MILL EFFLUENT BY Clostridium Acetobutylicum NCIMB 619
}

\section{(Kesan Penambahan Glukosa dalam Fermentasi Aseton-Butanol-Etanol daripada Efluen Kilang Kelapa Sawit oleh Clostridium Acetobutylicum NCIMB 619)}

\author{
Azima Syafaini Japar ${ }^{1 *}$, Mohd. Sobri Takriff ${ }^{2}$, Jamaliah Md. Jahim ${ }^{1}$, Abdul Amir Hassan Kadhum ${ }^{1}$ \\ ${ }^{I}$ Department of Chemical and Process Engineering \\ ${ }^{2}$ Research Center for Sustainable Process Technology \\ Faculty of Engineering and Built Environment, \\ Universiti Kebangsaan Malaysia, 43600, UKM Bangi, Selangor, Malaysia \\ *Corresponding author: azima.syafaini@siswa.ukm.edu.my
}

Received: 21 October 2015; Accepted: 14 June 2016

\begin{abstract}
This study investigates the production of acetone, butanol and ethanol (ABE) in sterilized sludge of palm oil mill effluent (POME) with the addition of glucose by Clostridium acetobutylicum NCIMB 619. Glucose concentrations of $5 \mathrm{~g} / \mathrm{L}, 10 \mathrm{~g} / \mathrm{L}$ and $15 \mathrm{~g} / \mathrm{L}$ were used with volume percentage of $3 \%(\mathrm{v} / \mathrm{v})$ and $5 \%(\mathrm{v} / \mathrm{v})$ for each concentration. The highest ABE production of 9.89 $\mathrm{g} / \mathrm{L}$ was observed with the addition of $10 \mathrm{~g} / \mathrm{L}$ glucose with volume percentage of $5 \%(\mathrm{v} / \mathrm{v})$ compared to $0.49 \mathrm{~g} / \mathrm{L}$ in the control batch, with highest $\mathrm{ABE}$ productivity and yield, $\mathrm{Y}_{\mathrm{P} / \mathrm{S}}$ of $0.14 \mathrm{~g} / \mathrm{L} / \mathrm{h}$ and $1.36 \mathrm{~g} \mathrm{ABE} / \mathrm{g}$ substrate, respectively. Providing culture with $15 \mathrm{~g} / \mathrm{L}$ glucose with volume percentage of $5 \%(\mathrm{v} / \mathrm{v})$ was found to reduce the ABE production with lower productivity and $\mathrm{ABE}$ yield. The lower production at higher sugar level might be due to sugar inhibition that occurred during the process.
\end{abstract}

Keywords: acetone-butanol-ethanol fermentation, palm oil mill effluent, Clostridium acetobutylicum, glucose addition

\begin{abstract}
Abstrak
Kajian ini dilakukan bagi menentukan kesan penamabahan glukosa terhadap penghasilan aseton, butanol dan etanol (ABE) di dalam medium mendakan efluen kilang kelapa sawit (POME) steril oleh Clostridium acetobutylicum NCIMB 619. Kepekatan glukosa yang digunakan adalah $5 \mathrm{~g} / \mathrm{L}, 10 \mathrm{~g} / \mathrm{L}$ dan $15 \mathrm{~g} / \mathrm{L}$ dengan peratus isipadu sebanyak 3\% (v/v) dan 5\% (v/v) bagi setiap kepekatan. Penghasilan ABE yang paling tinggi iaitu sebanyak $9.89 \mathrm{~g} / \mathrm{L}$ diperoleh pada penambahan $10 \mathrm{~g} / \mathrm{L}$ glukosa dengan peratus isipadu 5\% (v/v) berbanding $0.49 \mathrm{~g} / \mathrm{L} \mathrm{ABE}$ yang diperoleh di dalam medium kawalan. Produktiviti dan hasil ABE yang diperoleh juga adalah yang tertinggi iaitu masing-masing sebanyak $0.14 \mathrm{~g} / \mathrm{L} / \mathrm{j}$ dan $1.36 \mathrm{~g} \mathrm{ABE} / \mathrm{g}$ substrat. Penambahan $15 \mathrm{~g} / \mathrm{L}$ glukosa dengan peratus isipadu sebanyak $5 \%(\mathrm{v} / \mathrm{v})$ didapati mengurangkan penghasilan $\mathrm{ABE}$ dengan produktiviti dan hasil $\mathrm{ABE}$ yang paling rendah disebabkan oleh perencatan gula yang berlaku semasa proses fermentasi.
\end{abstract}

Kata kunci: fermentasi aseton-butanol-etanol, efluen kilang kelapa sawit, clostridium acetobutylicum, penambahan glukosa

\section{Introduction}

The biological production of Acetone-Butanol-Ethanol (ABE) via fermentation have started during the First World War declined 1960s due to introduction of chemical process and higher cost of raw materials [1]. The interest in $\mathrm{ABE}$ fermentation was once again increases due to the rapid depletion of petroleum resources, fluctuating fuel price 
as well as increase in public awareness on effects of toxic and greenhouse gases produced from fossil fuel combustion $[2,3]$. All these factors sparked in the attention of alternative fuels namely acetone, butanol and ethanol production through bioprocesses.

The most challenging aspects in $\mathrm{ABE}$ fermentation are to make the process economically feasible with zero competition with food crops to obtain raw material resources [4]. One of the solutions is to utilize industrial waste such as palm oil mill effluent (POME) that is readily available in Malaysia and able to reduce the cost of raw material. POME is an industrial waste that comes under the group of lignocellulose biomass consisting of various suspended components including cell wall, organelle and fiber, carbohydrate components which covered hemicellulose and simple sugar, nitrogenous compound including protein and amino acid and free organic acids and all these features make POME as a potential substrate for ABE fermentation [5-7].

POME characteristics as shown in Table 1 depend on the quality of raw material and method of oil processing in palm oil mill [8]. More than $50 \%$ of water used in crude oil production eventually ended up as POME $[9,10]$. POME was generated from three unit processes in a palm oil mill namely sterilization of fresh palm fruit (FFB) (38\%), clarification process of extracted crude oil (6\%) and hydro cyclone separation (4\%) [11]. Based on previous studies, ABE fermentation using POME as media can produce total solvent between 0.30 and $2.66 \mathrm{~g} / \mathrm{L}[7,12-15]$.

Several studies have reported that limited glucose content in the substrate produced higher amount of organic acids compared to ABE [1]. The cell metabolic shifting to ABE production will not occur if the glucose concentration in the substrate less than $7 \mathrm{~g} / \mathrm{L}[16,17]$. Other studies also reported that fermentation with limited presence of glucose resulting in the insufficient of final product of acids to achieve the desired amount of ABE [18-20]. Therefore, the objective of this study was to investigate the effect of glucose addition in ABE production via fermentation using sterilized POME sludge by C. acetobutylicum NCIMB 619.

Table 1. Characteristics of palm oil mill effluent (POME) [21]

\begin{tabular}{lrr}
\hline Parameter & Average & Range \\
\hline $\mathrm{pH}$ & 4.2 & $3.4-5.2$ \\
Biological oxygen demand $(\mathrm{BOD})(\mathrm{g} / \mathrm{L})$ & 25000 & $10250-43750$ \\
Chemical oxygen demand $(\mathrm{COD})(\mathrm{g} / \mathrm{L})$ & 51000 & $15000-100000$ \\
Total solid $(\mathrm{g} / \mathrm{L})$ & 40000 & $11500-79000$ \\
Suspended solid $(\mathrm{g} / \mathrm{L})$ & 18000 & $5000-54000$ \\
Volatile solid $(\mathrm{g} / \mathrm{L})$ & 34000 & $9000-72000$ \\
Oil and grease $(\mathrm{g} / \mathrm{L})$ & 6000 & $130-18000$ \\
Ammoniacal nitrogen $(\mathrm{g} / \mathrm{L})$ & 35 & $4-80$ \\
Total nitrogen $(\mathrm{g} / \mathrm{L})$ & 750 & $180-1400$ \\
\hline
\end{tabular}

\section{Organism, maintenance and inoculum preparation}

Materials and Methods

C. acetobutylicum NCIMB 619 was obtained from NCIMB Ltd (Aberdeen, UK) and the laboratory stocks were routinely maintained as spore suspensions in sterile deoxygenated Reinforced Clostridial Medium (RCM) at $37{ }^{\circ} \mathrm{C}$. Raw POME obtained from Sime Darby's East Palm Oil Mill in Carey Island was centrifuged at $2000 \mathrm{rpm}$ for 5 minutes to separate the supernatant and the sludge. Sterilization of the sludge was conducted using autoclave at $121{ }^{\circ} \mathrm{C}$ for 15 minutes.

\section{Fermentation process and analysis}

The fermentation process was carried out anaerobically in $250 \mathrm{~mL}$ conical flask at $37{ }^{\circ} \mathrm{C}$ for 72 hours with working volume of $170 \mathrm{~mL}$ without agitation and no $\mathrm{pH}$ correction was made. Glucose concentration of $5 \mathrm{~g} / \mathrm{L}$ (POME5), 
$10 \mathrm{~g} / \mathrm{L}$ (POME10) and $15 \mathrm{~g} / \mathrm{L}$ (POME15) were used with volume percentage of 3\% (v/v) and 5\% (v/v) for each concentration. The glucose was added into sterilized POME sludge and deoxygenated using purified nitrogen gas for 15 minutes to achieve the anaerobic condition. Samples for analysis of $\mathrm{pH}$, cell concentration, reducing sugar and solvents production were taken at regular interval. The $\mathrm{pH}$ values were determined using $\mathrm{pH}$ meter, while cell concentration and reducing sugar in the samples were determined by volatile suspended solid (VSS) and Miller methods [22], respectively. The concentrations of acetone, butanol, ethanol and organic acids were measured by gas chromatography (Eppendorf, German) that is equipped with flame ionization detector (FID) with initial operating temperature of $40^{\circ} \mathrm{C}$ for 8 minutes and then increased to $130{ }^{\circ} \mathrm{C}$ at the rate of $4{ }^{\circ} \mathrm{C} /$ minute for 2 minutes. The temperature of injector and detector was operated at $250{ }^{\circ} \mathrm{C}$ with helium as the carrier gas.

\section{Liquid-liquid extraction}

Liquid-liquid extraction was conducted to recover $\mathrm{ABE}$ from the fermentation broth before the samples were injected into gas chromatography. Oleyl alcohol was used as solvent which has been reported as a potential separation solvent for ABE [23]. Oleyl alcohol was added into the sample in centrifuge tube at the ratio of 1:1 (oleyl alcohol-sample). The solution was then mixed using vortex mixer at $1600 \mathrm{rpm}$ for 1 minute in order to increase the interaction between oleyl alcohol and the sample. To complete the phase separation, the solution was centrifuged at $2000 \mathrm{rpm}$ for 5 minutes. Assuming the organic and aqueous phase were separated completely, all samples were diluted with 99.5\% dichloromethane (DCM) at the ratio of 0.5:1 (DCM:sample). Samples from both phases were mixed by vortex mixer at $1600 \mathrm{rpm}$ for 1 minute to ensure the interaction between samples and DCM occurred effectively. A complete mixing will produce two layers of liquid due to the different density. The bottom layer was taken and filtered using $0.2 \mu \mathrm{m}$ nylon syringe filter before being transferred to sealed GC vial tubes for further analysis.

\section{Results and Discussion \\ ABE production with the addition of $3 \%(v / v)$ glucose}

The summary of total ABE and organic acids production is presented in Table 2 and Figure 1 with ethanol as the major product. It also shows that the production of $\mathrm{ABE}$ increased as the glucose concentration increased where in the control batch, only $0.49 \mathrm{~g} / \mathrm{L}$ ABE produced with a yield, $\mathrm{Y}_{\mathrm{P} / \mathrm{S}}$ of $0.04 \mathrm{~g} \mathrm{ABE} / \mathrm{g}$ substrate and productivity of $0.007 \mathrm{~g} / \mathrm{L} / \mathrm{h}$. POME15 produced the highest amount of ABE which is $3.44 \mathrm{~g} / \mathrm{L}$ with the production of acetic acid and butyric acid of $123.9 \mathrm{~g} / \mathrm{L}$ and $1.17 \mathrm{~g} / \mathrm{L}$, respectively. POME5 produced the lowest amount of ABE $(2.84 \mathrm{~g} / \mathrm{L})$ and produced the highest amount of organic acids which is $165.7 \mathrm{~g} / \mathrm{L}$ with $163.4 \mathrm{~g} / \mathrm{L}$ of acetic acid and $0.34 \mathrm{~g} / \mathrm{L}$ of butyric acid. All three medium produced a high concentration of acetic acid. ABE production was related to the activity of proteolysis enzyme that could affect the degradation of enzymes activity that involved in $\mathrm{ABE}$ fermentation [24]. The activity of proteolysis enzyme also might degrade the activity of tiolase enzyme that can change acetyl-CoA to acetoacetyl-CoA in the culture which is important in the production of acetone and butanol [25].

Table 2. Summary of ABE fermentation performance with the addition of $3 \%(v / v)$ glucose

\begin{tabular}{lccc}
\hline \multirow{2}{*}{ Parameter } & \multicolumn{3}{c}{ Glucose Concentration } \\
\cline { 2 - 4 } & $\mathbf{5} \mathbf{g} / \mathbf{L}$ & $\mathbf{1 0} \mathbf{g} / \mathbf{L}$ & $\mathbf{1 5} \mathbf{~ g / L}$ \\
\hline Initial $\mathrm{pH}$ & 4.26 & 4.27 & 4.30 \\
Max. cell concentration $(\mathrm{g} / \mathrm{L})$ & 63.5 & 59.0 & 58.0 \\
Total ABE $(\mathrm{g} / \mathrm{L})$ & 2.84 & 3.30 & 3.44 \\
A:B:E ratio & $0.2: 0.6: 9.2$ & $0.3: 0.7: 9$ & $0.3: 0.9: 8.8$ \\
Total organic acids $(\mathrm{g} / \mathrm{L})$ & 165.7 & 106.0 & 125.1 \\
Y $_{\mathrm{P} / \mathrm{s}}(\mathrm{g}$ ABE/g substrate) & 0.57 & 0.81 & 0.82 \\
$\mathrm{Y}_{\mathrm{X} / \mathrm{S}}(\mathrm{g}$ cell/g substrate) & 0.71 & 0.98 & 0.71 \\
Productivity $(\mathrm{g} / \mathrm{L} / \mathrm{h})$ & 0.04 & 0.05 & 0.05 \\
\hline
\end{tabular}


Azima Syafaini et al: THE EFFECT OF GLUCOSE ADDITION IN ACETONE-BUTANOL-ETHANOL FERMENTATION FROM PALM OIL MILL EFFLUENT BY Clostridium Acetobutylicum NCIMB 619

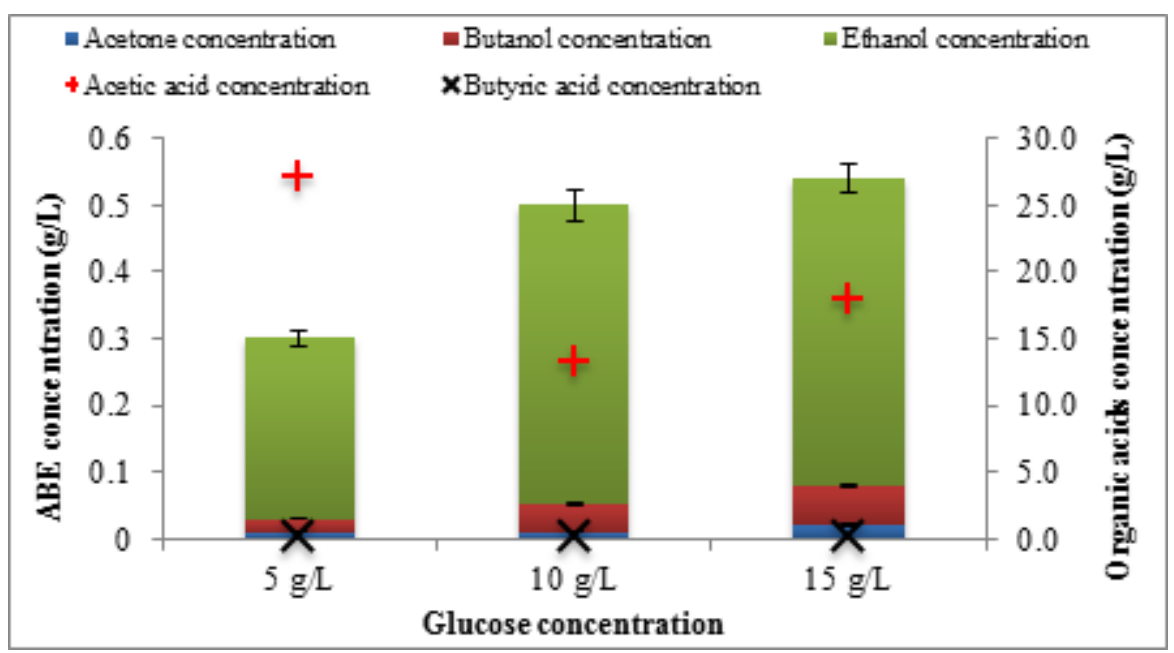

Figure 1. Maximum concentration of $\mathrm{ABE}$ and organic acids with the addition of $3 \%(\mathrm{v} / \mathrm{v})$ glucose

\section{ABE production with the addition of $5 \%$ ( $v / v)$ glucose}

Total production of $\mathrm{ABE}$ and organic acids with the addition of $5 \%(\mathrm{v} / \mathrm{v})$ glucose was summarized in Table 3 and Figure 2 with ethanol as the major product. For POME5 and POME10, the maximum ABE concentration of 0.50 $\mathrm{g} / \mathrm{L}$ and $0.52 \mathrm{~g} / \mathrm{L}$, respectively was collected after 48 hours of fermentation while for POME10, maximum ABE concentration of $1.95 \mathrm{~g} / \mathrm{L}$ was obtained after 72 hours of fermentation. POME5 produced $30.6 \%$ and $86.7 \%$ more acetone compared to POME15 and POME10.

Other than that, POME5 also produced $0.60 \mathrm{~g} / \mathrm{L}$ butanol which is two folds higher compared to POME15 that only produced $0.26 \mathrm{~g} / \mathrm{L}$ and $45.8 \%$ more butanol than that in POME10. At the same time, POME10 produced the highest concentration of ethanol which is $9.44 \mathrm{~g} / \mathrm{L}$ while POME5 and POME15 produced $2.87 \mathrm{~g} / \mathrm{L}$ and $1.88 \mathrm{~g} / \mathrm{L}$ ethanol, respectively. Total ABE of $9.89 \mathrm{~g} / \mathrm{L}$ produced in POME10 was the highest with total organic acids of $40.05 \mathrm{~g} / \mathrm{L}$. POME15 produced the lowest concentration of $\mathrm{ABE}(2.82 \mathrm{~g} / \mathrm{L})$ with organic acids concentration of $6.83 \mathrm{~g} / \mathrm{L}$.

Table 3. Summary of ABE fermentation performance with the addition of $5 \%(v / v)$ glucose

\begin{tabular}{lccc}
\hline \multirow{2}{*}{ Parameter } & \multicolumn{3}{c}{ Glucose Concentration } \\
\cline { 2 - 4 } & $\mathbf{5} \mathbf{~ g / L}$ & $\mathbf{1 0} \mathbf{g} / \mathbf{L}$ & $\mathbf{1 5} \mathbf{~ g / L}$ \\
\hline Initial $\mathrm{pH}$ & 4.30 & 4.48 & 4.31 \\
Max. cell concentration $(\mathrm{g} / \mathrm{L})$ & 63.5 & 59.0 & 62.3 \\
Total ABE $(\mathrm{g} / \mathrm{L})$ & 4.45 & 9.89 & 2.82 \\
A:B:E ratio & $2.2: 1.3: 6.5$ & $0.13: 0.33: 9.5$ & $2.4: 0.9: 6.7$ \\
Total organic acids $(\mathrm{g} / \mathrm{L})$ & 0.14 & 40.05 & 6.83 \\
Y $_{\mathrm{P} / \mathrm{S}}(\mathrm{g}$ ABE/g substrate) & 0.62 & 1.36 & 0.28 \\
Y $_{\mathrm{X} / \mathrm{S}}(\mathrm{g}$ cell/g substrate $)$ & 0.84 & 0.76 & 1.63 \\
Productivity $(\mathrm{g} / \mathrm{L} / \mathrm{h})$ & 0.06 & 0.14 & 0.04 \\
\hline
\end{tabular}




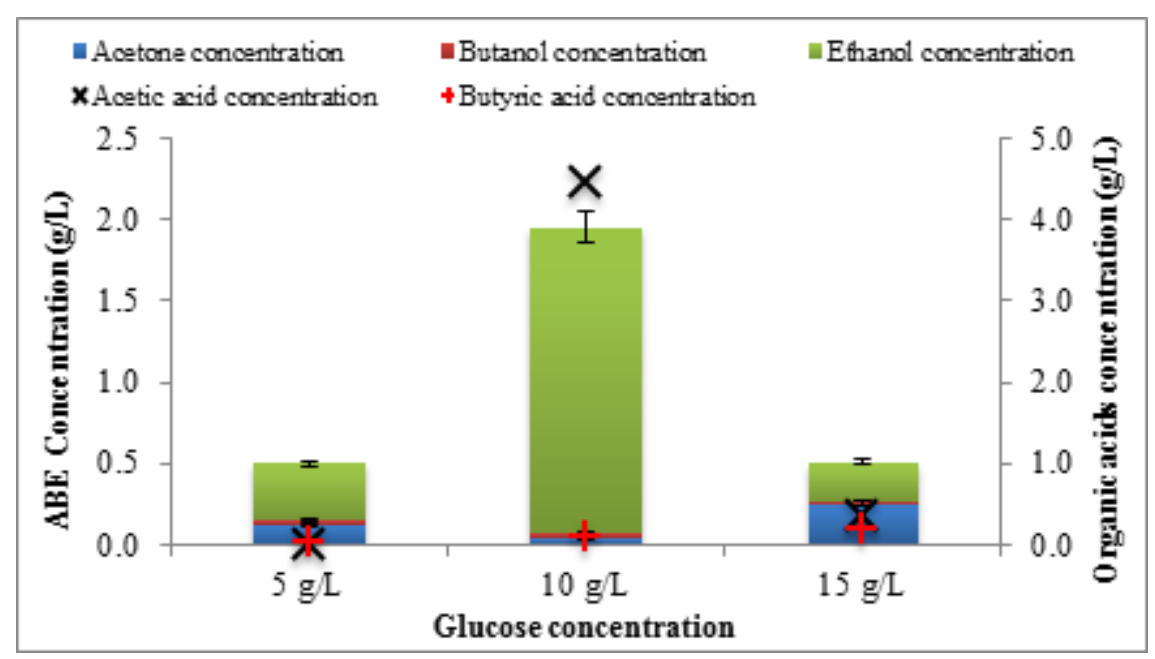

Figure 2. Maximum concentration of ABE and organic acids with the addition of $5 \%(\mathrm{v} / \mathrm{v})$ glucose

\section{Comparison of ABE fermentation performance with the addition of $3 \%(v / v)$ and $5 \%(v / v)$ glucose}

Based on Figure 3, it was found that with the addition of 3\% (v/v) glucose, enhanced the ABE production where in control batch, only $0.49 \mathrm{~g} / \mathrm{L}$ ABE was produced with yield, $\mathrm{Y}_{\mathrm{P} / \mathrm{S}}$ of $0.04 \mathrm{~g} \mathrm{ABE} / \mathrm{g}$ substrate and productivity of 0.007 $\mathrm{g} / \mathrm{L} / \mathrm{h}$ (Data was not shown). POME5 produced $2.84 \mathrm{~g} / \mathrm{L}$ ABE with yield, $\mathrm{Y}_{\mathrm{P} / \mathrm{S}}$ of $0.57 \mathrm{~g} \mathrm{ABE} / \mathrm{g}$ substrate. POME10 and POME15 produced $3.30 \mathrm{~g} / \mathrm{L}$ ABE with yield, $\mathrm{Y}_{\mathrm{P} / \mathrm{S}}$ of $0.81 \mathrm{~g}$ ABE/g substrate and $3.44 \mathrm{~g} / \mathrm{L} \mathrm{ABE}$ with yield, $\mathrm{Y}_{\mathrm{P} / \mathrm{s}}$ of $0.82 \mathrm{~g} \mathrm{ABE} / \mathrm{g}$ substrate, respectively.

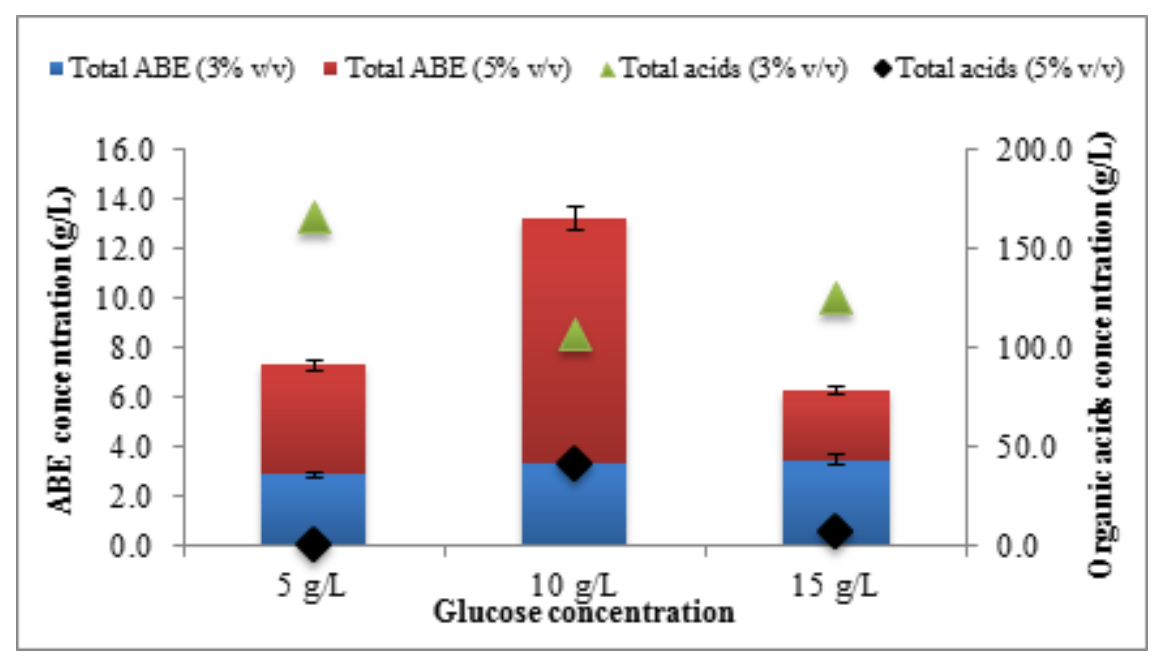

Figure 3. Comparison of ABE performances with the addition of glucose

However, ABE production was decreased at $15 \mathrm{~g} / \mathrm{L}$ glucose with the addition of $5 \%(\mathrm{v} / \mathrm{v})$ where high level of sugar in the medium was found to inhibit the production of $\mathrm{ABE}$ [26]. ABE fermentation using a high carbon source concentration may be controlled by the mass transfer rate, where high concentration carbon source could increase the viscosity of the culture and reduced the rate of mass transfer altogether [27]. 
Other than that, POME10 produced the highest ABE concentration which is $9.89 \mathrm{~g} / \mathrm{L}$ with yield, $\mathrm{Y}_{\mathrm{P} / \mathrm{S}}$ of $1.36 \mathrm{~g}$ $\mathrm{ABE} / \mathrm{g}$ substrate while POME5 and POME15 produced $4.45 \mathrm{~g} / \mathrm{L}$ and $2.82 \mathrm{~g} / \mathrm{L}$ ABE, respectively where POME15 produced the lowest yield, $\mathrm{Y}_{\mathrm{P} / \mathrm{S}}$ of $0.28 \mathrm{~g} \mathrm{ABE} / \mathrm{g}$ substrate. It was also found that the addition of $3 \%(\mathrm{v} / \mathrm{v})$ glucose produced the highest amount of organic acids that might be due to the acid crash that occurred when the undissociated acids in the culture was more than $57-60 \mathrm{mmol} / \mathrm{L}$ [28]. Furthermore, the results obtained from this study are comparable to previous reports as shown in Table 4.

Table 4. Comparison of ABE fermentation performances

\begin{tabular}{llccccc}
\hline Species & Substrate & $\begin{array}{c}\text { Glucose } \\
\text { Content } \\
(\mathbf{g} / \mathbf{L})\end{array}$ & $\begin{array}{c}\text { ABE } \\
\text { Concentration } \\
(\mathbf{g} / \mathbf{L})\end{array}$ & $\begin{array}{c}\text { Yield, } \mathbf{Y}_{\mathbf{P} / \mathbf{S}} \\
\mathbf{( g ~ A B E} / \mathbf{g} \\
\mathbf{s u b s t r a t e})\end{array}$ & $\begin{array}{c}\text { Productivity } \\
\text { (g/L/h) }\end{array}$ & Reference \\
\hline $\begin{array}{l}\text { C. acetobutylicum } \\
\text { NCIMB 619 }\end{array}$ & Raw POME & 3.40 & 2.05 & 0.90 & 0.04 & {$[15]$} \\
$\begin{array}{l}\text { C. beijerinckii } \\
\text { BA101 }\end{array}$ & $\begin{array}{l}\text { Treated } \\
\text { corn fiber }\end{array}$ & 23.60 & 9.30 & nd. & nd. & {$[29]$} \\
$\begin{array}{l}\text { C. acetobutylicum } \\
\text { ATCC 824 }\end{array}$ & $\begin{array}{l}\text { Spoilage } \\
\text { date palm }\end{array}$ & 36.20 & 10.42 & nd. & 0.14 & {$[30]$} \\
$\begin{array}{l}\text { C. beijerinckii } \\
\text { ATCC 55025 }\end{array}$ & Wheat bran & 21.30 & 11.80 & 0.32 & 0.16 & {$[31]$} \\
$\begin{array}{l}\text { C. acetobutylicum } \\
\text { NCIMB 619 }\end{array}$ & Sterilized & 15.82 & 9.89 & 1.36 & 0.14 & This study \\
\hline
\end{tabular}

*nd. - not determine

\section{Conclusion}

The addition of glucose in sterilized POME media was found to increase the ABE production. Based on the results of this study, the production of $\mathrm{ABE}$ and organic acids is higher as the glucose concentration increasing using $3 \%$ $(\mathrm{v} / \mathrm{v})$. However, for the glucose addition of $5 \%(\mathrm{v} / \mathrm{v})$, the high level of sugar present in the culture was found to inhibit the $\mathrm{ABE}$ production. Glucose concentration of $10 \mathrm{~g} / \mathrm{L}$ produced the highest concentration of $\mathrm{ABE}(9.89 \mathrm{~g} / \mathrm{L})$ with product yield, $\mathrm{Y}_{\mathrm{P} / \mathrm{S}}$ of $1.36 \mathrm{~g} \mathrm{ABE} / \mathrm{g}$ substrate while glucose concentration of $15 \mathrm{~g} / \mathrm{L}$ produced the lowest concentration of $\mathrm{ABE}$ and product yield, $\mathrm{Y}_{\mathrm{P} / \mathrm{S}}$ with $2.82 \mathrm{~g} / \mathrm{L}$ and $0.28 \mathrm{~g} \mathrm{ABE} / \mathrm{g}$ substrate, respectively.

\section{Acknowledgment}

The authors wish to thank Yayasan Sime Darby for funding the research through a grant number PKT6/2012.

\section{References}

1. Jones, D. T. and Woods, D. R. (1986). Acetone-butanol fermentation revisited. Microbiology and Molecular Biology Reviews, 50 (4): 484 - 524.

2. Wyman, C. E. (2007). What is (and is not) vital to advancing cellulosic ethanol. Trends Biotechnology, 25: 153 $-157$.

3. Lynd, L. R., Laser, M. S., Bransby, D., Dale, B. E., Davison, B. and Hamilton, R. (2008). How biotech can transform biofuels. Nature Biotechnology, 26: $169-172$.

4. Rajeev, K. S., Lalitha, D. G., Kuniparambil, R., Deepthy, A. and Ashok, P. (2011). Butanol fuel from biomass: revisiting ABE fermentation. Biofuels: Alternative feedstocks and conversion processes: pp. $571-586$.

5. Ugoji, E. (1997). Anaerobic digestion of palm oil mill effluent and its utilization as fertilizer for environmental protection. Renewable Energy, 10: 291 - 294.

6. Somrutai, W., Takagi, M. and Yoshida, T. (1996). Acetone-butanol fermentation by Clostridium aurantibutyricum ATCC 17777 from a model medium for palm oil mill effluent. Journal of Fermentation and Bioengineering, 81: 543 - 547. 
7. Kalil, M. S., Pang, W. K., Wan Yusoff, W. M., Sadazo, Y. and Abdul Rahman, R. (2003). Direct fermentation of palm oil mill effluent to acetone-butanol-ethanol by solvent producing Clostridia. Pakistan Journal of Biological Sciences, 6: $1273-1275$.

8. Parveen, F. R., Rajeev, P. S., Hakimi Ibrahim, M. and Esa, N. (2010). Review of current palm oil mill effluent (POME) treatment methods: Vermicomposting as a sustainable practice. World Applied Sciences Journal, 10 (10): $1190-1201$.

9. Ma, A. N. (1999). Treatment of palm oil mill effluent. In. Oil palm and the environment: A Malaysian perspective. Kuala Lumpur: Malaysia Oil Palm Grower's Council: 113 - 126.

10. Ahmad, A. L., Ismail, S. and Bhatia, S. (2003). Water recycling from palm oil mill effluent (POME) using membrane technology. Desalination, 157: 87 - 95.

11. Sethupathi, S. (2004). Removal of residues oil from palm oil mill effluent (POME) using chitosan, Thesis Universiti Sains Malaysia.

12. Azima, S. J., Mohd Sobri, T., Jamaliah, M. J. and Abd Amir, H. K. (2014). The potential of supernatant and sludge of POME in ABE fermentation by Clostridium acetobutylicum. Australian Journal of Basic and Applied Sciences 8(19): $44-46$.

13. Japar, A.S., Takriff, M. S., Jahim, J. M. and Kadhum, A. A. H. (2013). Acetone-butanol-ethanol fermentation from palm oil mill effluent using Clostridium acetobutylicum. Developments in Sustainable Chemical and Bioprocess. New York: Springer Science \& Business Media: pp. $35-41$.

14. Yusof, S. J. H. M. (2010). Fermentasi aseton-butanol-etanol (ABE) dan perolehan ABE daripada kaldu fermentasi. Thesis Master. Universiti Kebangsaan Malaysia.

15. Masngut, N. (2007). Aplikasi reaktor aliran berayun bagi penghasilan aseton-butanol-etanol oleh Clostridium acetobutylicum NCIMB 13357. Thesis Master. Universiti Kebangsaan Malaysia.

16. Long, S., Jones, D. T. and Woods, D. R. (1984). The relationship between sporulation and solvent production in Clostridium acetobutylicum P262. Biotechnology Letters, 6: 529 - 534.

17. Monot, F., Engasser, J. M. and Petitdemange, H. (1983). Regulation of acetone butanol production in batch and continuous cultures of Clostridium acetobutylicum. Biotechnology Symposium, 13: $207-216$.

18. Bahl, H., Andersch, W., Braun, K. and Gottschalk, G. (1982). Effect of pH and butyrate concentration on the production of acetone and butanol by Clostridium acetobutylicum grown in continuous culture. European Journal of Applied Microbiology and Biotechnology, 14: 17 - 20.

19. Haggstrom, L. and Enfors, S. O. (1982). Continuous production of butanol with immobilized cells of Clostridium acetobutylicum. Applied Biochemistry and Biotechnology, 7: $35-37$.

20. Rogers, P. (1984). Genetics and biochemistry of Clostridium relevant to development of fermentation processes. Applied Microbiology, 31: 1 - 60.

21. Malaysian Palm Oil Board, MPOB. (2012). Oil palm and the environment. www.mpob.com.my/en/palminfo/environment/520-achievements [20 Mac 2013].

22. Miller, G. L. (1959). Use of dinitrosalicylic acid reagent for determination of reducing sugar. Analytical Chemistry 31: $426-429$.

23. Boudreau, T. M. and Gordon, A. H. (2006). Improved ethanol-water separation using fatty acids. Process Biochemistry, 41: $980-983$.

24. Yaacob, N. S. (2003). Performance of solvent (acetone-butanol-ethanol) fermentation by Clostridium saccharobutylicum strain P262 and NCIMB 8052 using free and immobilized cells system. Thesis Master. Universiti Putra Malaysia.

25. Lee, S. Y., Park, J. H., Jang, S. H., Nielsen, L. K., Kim, J. and Jung, K. S. (2008). Fermentative butanol production by clostridia. Biotechnology and Bioengineering, 101 (2): $209-228$.

26. Qureshi, N., Cotta, M. A. and Saha, B. C. (2013). Bioconversion of barley straw and corn stover to butanol (a biofuel) in integrated fermentation and simultaneous product recovery bioreactors. Food and Bioproducts Processing, 92(3): $298-308$.

27. Madihah, M. S., Sahaid, K. M., Suraini, A. A. and Karim, M. I. A. (2001). Direct fermentation of gelatinized sago starch to acetone-butanol-ethanol by Clostridium acetobutylicum. World Journal of Microbiology \& Biotechnology, 17: $567-576$.

28. Gao, K and Rehmann, L. (2014). ABE fermentation from enzymatic hydrolysate of NAOH-pretreated corncobs. Biomass and Bioenergy, 66: $110-115$. 
29. Qureshi, N., Saha, B. C., Hector, R. E. and Cotta, M. A. (2008). Removal of fermentation inhibitors from alkaline peroxide pretreated and enzymatically hydrolyzed wheat straw: Production of butanol from hydrolysate using Clostridium beijerinckii in batch reactors. Biomass and Bioenergy, 32: 1353 -1358.

30. Abd-Alla, M. H and El-Enany, A. E. (2012). Production of acetone-butanol-ethanol from spoilage date palm (Phoenix dactylifera L.) fruits by mixed culture of Clostridium acetobutylicum and Bacillus subtilis. Biomass and Bioenergy, 42: $172-178$.

31. Liu, Z., Ying, Y., Li., F., Ma, C. and Xu, P. (2010). Butanol production by Clostridium beijerinckii ATCC 55025 from wheat bran. Journal of Industrial Microbiology \& Biotechnology, 37 (5): 495 - 501. 